\title{
MODEL-MODEL PEMBELAJARAN DALAM MATA PELAJARAN IPA
}

\section{A. Pendahuluan}

Istilah model pembelajaran amat dekat dengan pengertian strategi pembelajaran dan dibedakan dari istilah strategi, pendekatan dan metode pembelajaran. Istilah model pembelajaran mempunyai makna yang lebih luas daripada suatu strategi, metode, dan teknik. Sedangkan istilah "strategi " awal mulanya dikenal dalam dunia militer terutama terkait dengan perang atau dunia olah raga, namun demikian makna tersebut meluas tidak hanya ada pada dunia militer atau olahraga saja akan tetapi bidang ekonomi, sosial, pendidikan. Menurut Ruseffendi (1980), istilah strategi, metode, pendekatan dan teknik mendefinisikan sebagai berikut :

1. Strategi pembelajaran adalah separangkat kebijaksanaan yang terpilih, yang telah dikaitkan dengan faktor yang menetukan warna atau strategi tersebut, yaitu :

a. Pemilihan materi pelajaran (guru atau siswa)

b. Penyaji materi pelajaran (perorangan atau kelompok, atau belajar mandiri)

c. Cara menyajikan materi pelajaran (induktif atau deduktif, analitis atau sintesis, formal atau non formal)

d. Sasaran penerima materi pelajaran ( kelompok, perorangan, heterogen, atau homogen.

2. Pendekatan Pembelajaran adalah jalan atau arah yang ditempuh oleh guru atau siswa dalam mencapai tujuan pembelajaran dilihat bagaimana materi itu disajikan. Misalnya memahami suatu prinsip dengan pendekatan induktif atau deduktif.

3. Metode Pembelajaran adalah cara mengajar secara umum yang dapat diterapkan pada semua mata pelajaran, misalnya mengajar dengan ceramah, ekspositori, tanya jawab, penemuan terbimbing dan sebagainya.

4. Teknik mengajar adalah penerapan secara khusus suatu metode pembelajaran yang telah disesuaikan dengan kemampuan dan kebiasaan guru, ketersediaan media pembelajaran serta kesiapan siswa. Misalnya teknik mengajarkan perkalian dengan penjumlahan berulang.

Sedangkan Model Pembelajaran adalah sebagai suatu disain yang menggambakan proses rincian dan penciptaan situasi lingkungan yang memungkinkan siswa berinteraksi sehingga terjadi perubahan atau perkembangan pada diri siswa

Sedangkan menurut Kamus Besar Bahasa Indonesia (2003 : 203), pengertian strategi (1) ilmu dan seni menggunakan sumber daya bangsa untuk melaksanakan kebijaksanaan tertentu dalam dan perang damai, (2) rencana yang cermat mengenai kegiatan untuk mencapai sasaran khusus. Soedjadi (1999 :101) menyebutkan strategi pembelajaran adalah suatu siasat melakukan kegiatan pembelajaran yang 
bertujuan mengubah keadaan pembelajaran menjadi pembelajaran yang diharapkan. Untuk dapat mengubah keadaan itu dapat ditempuh dengan berbagai pendekatan pembelajaran. Lebih lanjut Soedjadi menyebutkan bahwa dalam satu pendekatan dapat dilakukan lebih dari satu metode dan dalam satu metode dapat digunakan lebih dari satu teknik.Secara sederhana dapat dirunut sebagai rangkaian :

teknik $\rightarrow$ metode $\rightarrow$ pendekatan $\rightarrow$ strategi $\longrightarrow$ model

Istilah "model pembelajaran" berbeda dengan strategi pembelajaran, metode pembelajaran, dan pendekatan pembelajaran. Model pembelajaran meliputi suatu model pembelajaran yang luas dan menyuluruh. Konsep model pembelajaran lahir dan berkembang dari pakar psikologi dengan pendekatan dalam setting eksperimen yang dilakukan. Konsep model pembelajaran untuk pertama kalinya dikembangkan oleh Bruce dan koleganya (Joyce, Weil dan Showers, 1992)

Lebih lanjut Ismail (2003) menyatakan istilah Model pembelajaran mempunyai empat ciri khusus yang tidak dipunyai oleh strategi atau metode tertentu yaitu :

1. rasional teoritik yang logis disusun oleh perancangnya,

2. tujuan pembelajaran yang akan dicapai,

3. tingkah laku mengajar yang diperlukan agar model tersebut dapat dilaksanakan secara berhasil dan

4. lingkungan belajar yang diperlukan agar tujuan pembelajaran itu dapat tercapai.

Model pembelajaran (Teaching Models) atau (Models of Teaching) memiliki makna lebih luas dari metode, strategi/pendekatan dan prosedur. Istilah model pembelajaran adalah pendekatan tertentu dalam pembelajaran yang tercakup dalam tujuan, sintaks, lingkungan dan sistem manajemen (Arends, 1997:7) Adapun ciri-ciri dari model pembelajaran dapat digambarkan sebagai berikut.

Memiliki Rasionalisasi Teoritis

Terkait Dengan Hasil Pembelajaran

Menuntut Perilaku Guru

Menuntut Struktur Kelas

Sintak dalam model pembelajaran merupakan urutan tahap-tahap yang selalu diikuti dalam pembelajaran.

Berbedanya pengertian antara model, strategi, pendekatan dan metode serta teknik diharapkan guru mata pelajaran umumnya dan khususnya ilmu pengetahuan alam mampu memilih model dan mempunyai strategi pembelajaran yang sesuai dengan materi dan kompetensi dalam kurikulum. 


\section{B. Model Pembelajaran IImu Pengetahuan Alam}

Jenis-jenis model pembelajaran dalam pembelajaran IPA di sekolah antara lain: model pembelajaran langsung (Direct Instruction), model pembelajaran Children Learning In science (CLIS), dan model pembelajaran berbasis masalah (Problem Based Instructions).

\section{Model Pembelajaran Langsung}

Pembelajaran langsung dirancang secara khusus untuk mengembangkan pembelajaran siswa tentang pengetahuan prosedural dan pengetahuan deklarasi yang terstruktur dengan baik dan dapat dipelajari selangkah demi selangkah.

Sintaks model pembelajaran langsung adalah sebagai berikut.

\begin{tabular}{|l|l|}
\hline \multicolumn{1}{|c|}{ Fase } & \multicolumn{1}{|c|}{ Peran Guru } \\
\hline $\begin{array}{l}\text { 1. menyampaikan tujuan } \\
\text { dan mempersiapkan }\end{array}$ & $\begin{array}{l}\text { Guru menjelaskan tujuan, informasi latar } \\
\text { belakang pelajaran, pentingnya pelajaran, } \\
\text { mempersiapkan siswa untuk belajar }\end{array}$ \\
\hline $\begin{array}{l}\text { 2. mendemonstrasikan } \\
\text { pengetahuan atau } \\
\text { keterampilan }\end{array}$ & $\begin{array}{l}\text { Guru mendemonstrasikan keterampilan atau } \\
\text { menyajikan informasi setahap demi setahap }\end{array}$ \\
\hline 3. membimbing pelatihan & Guru memberikan pelatihan awal \\
\hline $\begin{array}{l}\text { 4. mengecek pemahaman } \\
\text { dan pemberian umpan } \\
\text { balik }\end{array}$ & $\begin{array}{l}\text { Mengecek apakah siswa telah berhasil } \\
\text { melakukan tugas dengan baik, memberi umpan } \\
\text { balik m mempersiapkan kesempatan untuk }\end{array}$ \\
\hline $\begin{array}{l}\text { 5. memberi kesempatan } \\
\text { untuk pelatihan lanjutan } \\
\text { dan penerapan }\end{array}$ & $\begin{array}{l}\text { Guru melakukan pelatihan lanjutan, dengan perhatian } \\
\text { melakuk pada penerapan untuk situasi lebih } \\
\text { khusus pun } \\
\text { kompleks dalam kehidupan sehari-hari }\end{array}$ \\
\hline
\end{tabular}

\section{Model Pembelajaran Children Learning In science (CLIS)}

\section{Pengertian model pembelajaran Children Learning In Science (CLIS)}

Model pembelajaran CLIS adalah kerangka berpikir untuk menciptakan lingkungan yang memungkinkan terjadinya kegiatan belajar mengajar yang melibatkan siswa dalam kegiatan pengamatan dan percobaan dengan menggunakan LKS. Model pembelajaran CLIS bertujuan membentuk pengetahuan (konsep) ke dalam memori siswa agar konsep tersebut dapat bertahan lama, karena model pembelajaran CLIS memuat sederetan tahap-tahap kegiatan siswa dalam mempelajari konsep yang diajarkan. Menurut Driver (1988) tahapantahapan CLIS secara umum seperti gambar di bawah ini 


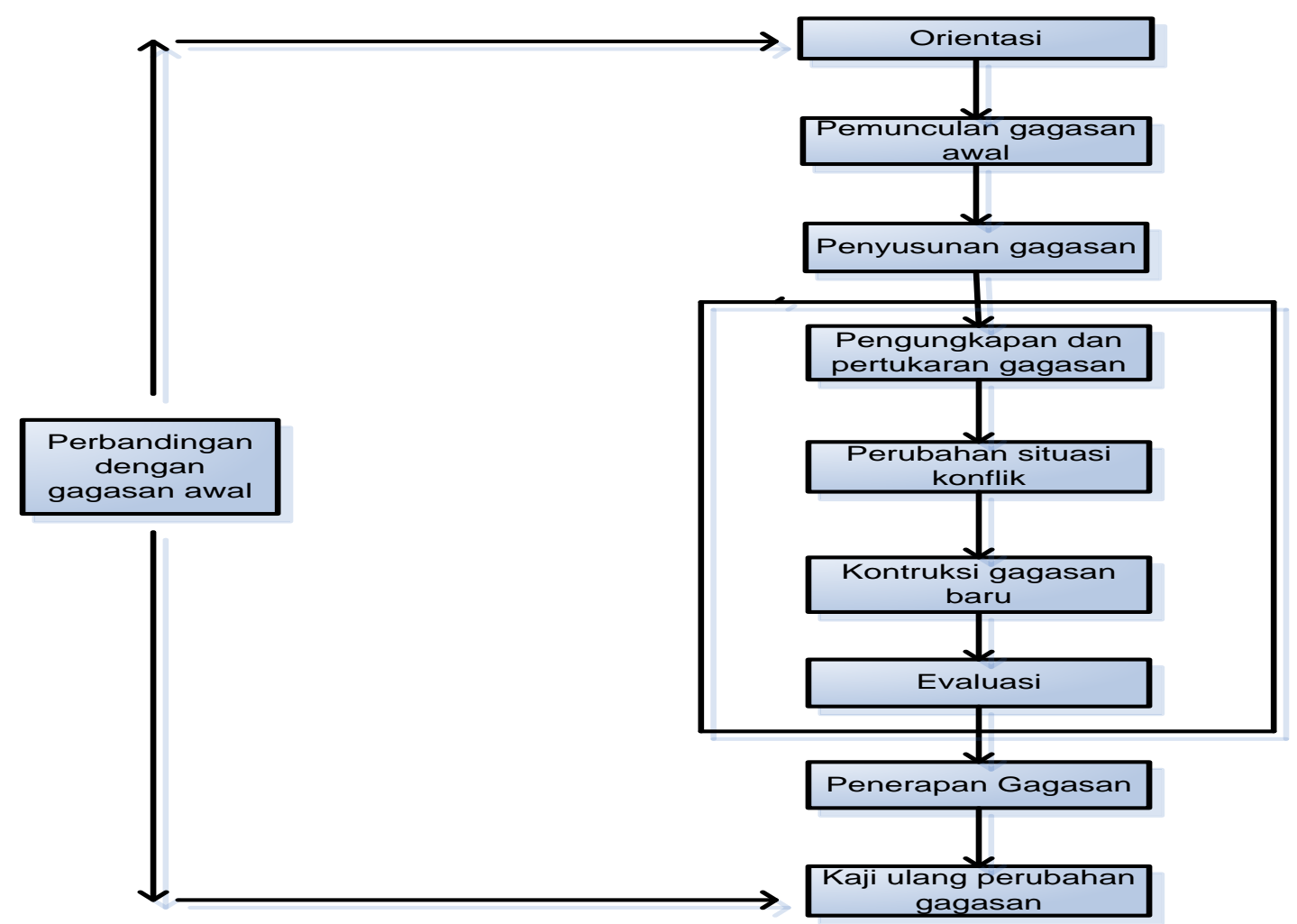

Gambar model pembelajaran CLIS

Tahapan-tahapan di atas dijelaskan sebagai berikut:

1. Orientasi

Pada tahap ini guru memusatkan perhatian siswa dengan menanyakan tentang fenomena alam yang sering dijumpai siswa pada kehidupan seharihari yang ada kaitanya dengan meteri yang akan diajarkan.

2. Pemunculan gagasan awal

Pada tahap ini guru mengungkap konsepsi awal siswa dengan menghadapkan siswa pada suatu permasalahan yang mengadung teka-teki.

3. Penyusunan gagasan

Tahap ini terdiri dari pengungkapan dan pertukaran gagasan, perubahan situasi konflik,kontruksi gagasan baru,dan evaluasi. Siswa diberikan LKS dan melakukan kegiatan belajar dalam kelompok secara berdiskusi dan bertukar gagasan untuk menjawab pertanyaan dan masalah dalam LKS

4. Penerapan gagasan

Pada tahap ini siswa menjawab pertanyaan yang disusun dalam LKS untuk menerapkan kosep ilmiah mengenai permasalahan dalam kehidupan seharihari.

5. Kaji ulang perubahan gagasan

Pada tahap ini siswa diberi kesempatan untuk melakukan refleksi terhadap hasil pembelajaran yang telah diperoleh. 


\section{Karakteristik model pembelajaran Children Learning In Science (CLIS)}

Berdasarkan tahapan-tahapan yang dilaksanakan pada model pembelajaran CLIS maka dapat dikemukakan karakteristik model pembelajaran CLIS antara lain:

1) Dilandasi oleh pandangan konstruktivisme

2) Pembelajaran berpusat pada siswa

3) Melakukan aktifitas hands on/ minds on

4) Menggunakan lingkungan sebagai sumber belajar

Faktor-faktor penting dalam pelaksanaan pembelajaran model pembelajaran CLIS ini adalah:

1) Menciptakan situasi belajar terbuka dan memberikan kebebasan pada siswa dalam mengemukakan ide atau gagasan.

2)Memberikan kesempatan pada siswa untuk bertanya pada teman atau gurunya, kemudian pada akhir kegiatan pembelajaran guru menjelaskan konsep-konsep ilmiah untuk menghidari miskonsepsi pada siswa.

3)Memberikan tugas perorangan yang dikerjakan siswa di rumah berupa PR sebagai penerapan konsep.

Kelebihan dan kelemahan model pembelajaran Children Learning In Science (CLIS)

Kelebihan-kelebihan CLIS sebagai berikut :

1) Gagasan anak lebih mudah dimunculkan.

2) Membiasakan siswa untuk belajar mandiri dalam memecahkan suatu masalah.

3) Empat syarat perubahan konsepsi yang dikemukakan oleh posner et al terpenuhi.

4) Menciptakan kreatifitas siswa untuk belajar sehingga tercipta suasana kelas yang lebih nyaman dan kreatif, terjadi kerjasama sesama siswa dan siswa terlibat langsung dalam melakukan kegiatan.

5) Menciptakan belajar yang lebih bermakna karena timbulnya kebanggaan siswa menemukan sendiri konsep ilmiah yang dipelajari.

6) Guru mengajar akan lebih efektif karena dapat menciptakan suasana belajar yang aktif

Adapun kelemahan CLIS adalah sarana laboratorium harus lengkap, kemudian siswa yang belum terbiasa belajar mandiri atau berkelompok akan merasa asing dan sulit untuk menguasai konsep. 


\section{Model Pembelajaran Berdasarkan Masalah}

\section{Pengertian pembelajaran berbasis masalah}

Pembelajaran berbasis masalah dikembangkan untuk pertama kali oleh Howard Barrows pada awal tahun 70 an dalam pembelajaran ilmu medis di Southern Illinois University School of Medicine, yang merupakan pengembangan dari model McMasters (Barrows, 1980 dalam Karim et.al., 2007).

Beberapa definisi tentang pembelajaran berbasis masalah:

1. Pembelajaran berbasis masalah merupakan sebuah pendekatan pembelajaran yang menyajikan masalah kontekstual sehingga merangsang siswa untuk belajar. Dalam kelas yang menerapkan pembelajaran berbasis masalah, siswa bekerja dalam tim untuk memecahkan masalah dunia nyata (real world) (Major, Claire.H dan Palmer, Betsy, 2001).

2. Pembelajaran berbasis masalah merupakan suatu metode pembelajaran yang menantang siswa untuk "belajar bagaimana belajar", bekerja secara berkelompok untuk mencari solusi dari permasalahan dunia nyata. Masalah ini digunakan untuk mengikat siswa pada rasa ingin tahu pada pembelajaran yang dimaksud (Duch J.B, 1995).

3. Pembelajaran berbasis masalah adalah strategi pembelajaran yang merangsang siswa aktif untuk memecahkan permasalahan dalam situasi nyata (Evan Glazer, 2001).

Dari beberapa uraian mengenai pengertian pembelajaran berbasis masalah, dapat disimpulkan bahwa pembelajaran berbasis masalah (PBM) merupakan pembelajaran yang menghadapkan siswa pada masalah dunia nyata (real world) untuk memulai pembelajaran. Pembelajaran berbasis masalah merupakan suatu pengembangan kurikulum dan model pembelajaran. Barbara J. Duch (1995 dalam Karim et al., 2007) mengemukakan bahwa : in problem based learning $(P B L)$, students are presented with an interesting, relevant problem "up front". So that they can eXperience for them selves the process of doing science. Dalam pembelajaran berbasis masalah, siswa memiliki peran sebagai problem-solvers sedangkan guru memiliki peranan sebagai tutor atau pelatih. Dalam artikel tentang pembelajaran berbasis masalah (PBM) yang ditulis di Website IMSA (Illinois Mathematics and Science Academy) dinyatakan bahwa motivasi pengembangan PBM adalah :" to makes students engaged in learning because they are hard wired to respond to dissonance and because they feel they are empowered to have an impact on the outcome of the investigation" (Abbas, 2000 dalam Karim et.al., 2007). 
Pembelajaran berbasis masalah merupakan pembelajaran dengan pendekatan konstruktivis, karena disini guru hanya berperan sebagai penyaji masalah, penanya, mengadakan dialog, pemberi fasilitas penelitian, menyiapkan dukungan dan dorongan yang dapat meningkatkan pertumbuhan inkuiri dan intelektual pada peserta didik. Prinsip utama pendekatan konstruktivis adalah pengetahuan tidak diterima secara pasif, tetapi dibangun secara aktif oleh siswa (Abbas, 2000 dalam Karim et.al.,2007).

Pembelajaran berbasis masalah mengutamakan proses belajar, dimana tugas guru harus memfokuskan diri untuk membantu peserta didik mengembangkan keterampilan dan kecakapan berpikir dalam mempelajari dan menyerap materi pembelajaran. Dengan demikian pembelajaran berbasis masalah dapat digunakan untuk melatih dan mengembangkan berbagai keterampilan dan kecakapan sains tingkat tinggi, serta meningkatkan pencapaian hasil belajar.

Hal ini sejalan dengan yang dikemukaan oleh Barbara J.Duch (2001) yang menyatakan bahwa beberapa kemampuan yang dapat dilatihkan dengan pembelajaran berbasis masalah adalah :

1. Berpikir kritis, menganalisis dan mampu memecahkan masalah dunia nyata.

2. Mencari, mengevaluasi, dan menggunakan sumber belajar secara tepat.

3. Kerja sama dalam kelompok (tim).

4. Cakap dalam menyajikan dan berkomunikasi secara efektif, baik secara lisan maupun tulisan.

5. Menggunakan pengetahuan dan kecakapan intelektual yang diperoleh untuk terus belajar.

\section{Karakteristik Pembelajaran Berbasis Masalah}

Ciri yang paling utama dari pembelajaran berbasis masalah yaitu dimunculkannnya masalah pada awal pembelajarannya. Selain itu, pembelajaran berbasis masalah mengutamakan proses belajar, dimana tugas guru harus memfokuskan diri untuk membantu peserta didik mengembangkan keterampilan dan kecakapan berpikir dalam mempelajari dan menyerap materi pembelajaran. Dengan demikian model pembelajaran ini dapat digunakan untuk melatih dan mengembangkan berbagai keterampilan dan kecakapan sains tingkat tinggi, serta meningkatkan pencapaian hasil belajar (Abbas, 2000 dalam Karim et.al., 2007).

Sementara itu, Akinoglu \& Tandagon (dalam Nurhasanah, 2007) mengemukakan enam karakteristik yang perlu diperhatikan dalam pembelajaran berbasis masalah. Pertama, proses belajar harus dimulai dengan suatu masalah, terutama masalah yang belum terpecahkan. Kedua, isi dari suatu permasalahan 
merupakan isu-isu yang menarik perhatian siswa. Ketiga, guru hanya sebagai fasilitator dalam kelas. Keempat, siswa harus diberi waktu untuk berpikir atau mengumpulkan informasi dan menyusun strategi pemecahan masalah, dalam proses ini pemikiran-pemikiran yang kreatif harus didukung. Kelima, tingkat kesukaran dari masalah yang akan dipecahkan tidak terlalu sulit sehingga bisa menakuti siswa. Keenam, kenyamanan dan keamanan lingkungan pembelajaran harus diciptakan untuk mengembangkan keterampilan-keterampilan berpikir siswa dan memecahkan masalah.

Selanjutnya Wang et.al (dalam Nurhasanah, 2007) mengemukakan tiga unsur esensial yang terdapat dalam pembelajaran berbasis masalah yaitu adanya suatu permasalahan, pembelajaran berpusat pada siswa dan belajar dalam kelompok kecil.

Masalah yang disajikan pada siswa harus dapat diselesaikan melalui kegiatan penyelidikan (investigation) dan penemuan (inquary). Savery dan Duffy (1995) mengemukakan dua hal yang harus dijadikan pedoman dalam menyajikan permasalahan. Pertama, permasalahan harus sesuai dengan konsep dan prinsip yang akan dipelajari. Kedua, permasalahan yang disajikan adalah permasalahan riil, artinya masalah itu nyata ada dalam kehidupan sehari-hari siswa.

Savote dan Hughes (dalam Ari Wahyu A, 2007) mengemukakan bahwa saat pemecahan masalah, proses yang akan dialami siswa adalah sebagai berikut.

a. Engagement. Siswa berperan secara aktif sebagai pemecah masalah. Siswa dihadapkan pada situasi yang mendorongnya untuk mampu menemukan masalah dan pemecahannya.

b. Inquary. Siswa bekerja sama dengan siswa lainnya untuk menemukan dan mengumpulkan informasi melalui kegiatan penyelidikan.

c. Solution Building. Siswa bekerja sama melakukan diskusi untuk menemukan penyelesaian permasalahan yang disajikan.

d. Debriefing and Reflection. Siswa melakukan sharing mengenai pendapat dan idenya dengan siswa lain melalui kegiatan tanya jawab untuk mengevaluasi proses dan hasil pemecahan masalah.

e. Presentation of Finding. Siswa menuliskan rencana, laporan kegiatan atau produk lain yang dihasilkannya selama pembelajaran, kemudian mempresentasikannya kepada siswa lain, misalnya di depan kelas.

\section{Tahapan Model Pembelajaran Berbasis Masalah}

Pelaksanaan pembelajaran berdasarkan masalah meliputi lima tahapan proses, yaitu : (Abas, 2000 dalam Karim et al., 2007) 
Tahap pertama, adalah proses orientasi peserta didik pada masalah. Pada tahap ini guru menjelaskan tujuan pembelajaran, menjelaskan logistik yang diperlukan, memotivasi peserta didik untuk terlibat dalam aktivitas pemecahan masalah, dan mengajukan masalah.

Tahap kedua, mengorganisasi peserta didik. Pada tahap ini guru membagi peserta didik kedalam kelompok, membantu peserta didik mendefinisikan dan mengorganisasikan tugas belajar yang berhubungan dengan masalah.

Tahap ketiga, membimbing penyelidikan individu maupun kelompok. Pada tahap ini guru mendorong peserta didik untuk mengumpulkan informasi yang dibutuhkan, melaksanakan eksperimen dan penyelidikan untuk mendapatkan penjelasan dan pemecahan masalah.

Tahap keempat, mengembangkan dan menyajikan hasil. Pada tahap ini guru membantu peserta didik dalam merencanakan dan menyiapkan laporan, dokumentasi, atau model, dan membantu mereka berbagi tugas dengan sesama temannya.

Tahap kelima, menganalisis dan mengevaluasi proses dan hasil pemecahan masalah. Pada tahap ini guru membantu peserta didik untuk melakukan refleksi atau evaluasi terhadap proses dan hasil penyelidikan yang mereka lakukan.

Tabel Tahapan Model Pembelajaran Berbasis Masalah

\begin{tabular}{|l|l|}
\hline \multicolumn{1}{|c|}{\begin{tabular}{c}
\multicolumn{1}{|c|}{ Tahapan } \\
Pembelajaran
\end{tabular}} & \multicolumn{1}{c|}{ Kegiatan Guru } \\
\hline $\begin{array}{l}\text { Orientasi peserta didik } \\
\text { pada masalah }\end{array}$ & $\begin{array}{l}\text { Menjelaskan tujuan pembelajaran, } \\
\text { menjelaskan logistik yang diperlukan, } \\
\text { memotivasi peserta didik untuk terlibat } \\
\text { dalam aktivitas pemecahan masalah, dan } \\
\text { mengajukan masalah. }\end{array}$ \\
\hline $\begin{array}{l}\text { Tahap 2 } \\
\text { Mengorganisasi peserta } \\
\text { didik }\end{array}$ & $\begin{array}{l}\text { Membagi peserta didik kedalam kelompok, } \\
\text { membantu peserta didik mendefinisikan } \\
\text { dan mengorganisasikan tugas belajar yang } \\
\text { berhubungan dengan masalah. }\end{array}$ \\
\hline $\begin{array}{l}\text { Tahap 3 } \\
\text { pembimbing } \\
\text { maupun kelompok }\end{array}$ & $\begin{array}{l}\text { Mendorong peserta didik untuk } \\
\text { mengumpulkan informasi yang dibutuhkan, } \\
\text { melaksanakan eksperimen dan } \\
\text { penyelidikan untuk mendapatkan } \\
\text { penjelasan dan pemecahan masalah. }\end{array}$ \\
\hline $\begin{array}{l}\text { Tahap 4 } \\
\text { Mengembangkan dan }\end{array}$ & $\begin{array}{l}\text { Membantu peserta didik dalam } \\
\text { merencanakan dan menyiapkan laporan, } \\
\text { dokumentasi, atau model, dan membantu }\end{array}$ \\
& $\begin{array}{l}\text { mereka berbagi tugas dengan sesama } \\
\text { temannya. }\end{array}$ \\
\hline $\begin{array}{l}\text { Tahap 5 } \\
\text { Menganalisis dan } \\
\text { mengevaluasi proses } \\
\text { dan hasil pemecahan } \\
\text { masalah }\end{array}$ & $\begin{array}{l}\text { Membantu peserta didik untuk melakukan } \\
\text { refleksi atau evaluasi terhadap proses dan } \\
\text { hasil penyelidikan yang mereka lakukan. }\end{array}$ \\
\hline
\end{tabular}




\section{Kelebihan dan Kelemahan Model Pembelajaran Berbasis Masalah Kelebihan}

Sebagai suatu model pembelajaran, pembelajaran berbasis masalah (PBM) memiliki beberapa kelebihan, diantaranya : (Wina Sanjaya, 2007)

1) Menantang kemampuan siswa serta memberikan kepuasan untuk menemukan pengetahuan baru bagi siswa.

2) Meningkatakan motivasi dan aktivitas pembelajaran siswa.

3) Membantu siswa dalam mentransfer pengetahuan siswa untuk memahami masalah dunia nyata.

4) Membantu siswa untuk mengembangkan pengetahuan barunya dan bertanggung jawab dalam pembelajaran yang mereka lakukan. Disamping itu, PBM dapat mendorong siswa untuk melakukan evaluasi sendiri baikterhadap hasil maupun proses belajarnya.

5) Mengembangkan kemampuan siswa untuk berpikir kritis dan mengembangkan kemampuan mereka untuk menyesuaikan dengan pengetahuan baru.

6) Memberikan kesemnpatan bagi siswa untuk mengaplikasikan pengetahuan yang mereka miliki dalam dunia nyata.

7) Mengembangkan minat siswa untuk secaraterus menerus belajar sekalipun belajar pada pendidikan formal telah berakhir.

8) Memudahkan siswa dalam menguasai konsep-konsep yang dipelajari guna memecahkan mkasalah dunia nyata.

\section{Kelemahan}

Disamping kebihan diatas, PBM juga memiliki kelemahan, diantaranya: (Wina Sanjaya, 2007)

1) Manakala siswa tidak memiliki minat atau tidak mempunyai kepercayaan bahwa masalah yang dipelajari sulit untuk dipecahkan, maka mereka akan merasa enggan untuk mencobanya.

2) Untuk sebagian siswa beranggapan bahwa tanpa pemahaman mengenai materi yang diperlukan untuk menyelesaikan masalah mengapa mereka harus berusaha untuk memecahkan masalah yang sedang dipelajari, maka mereka akan belajar apa yang mereka ingin pelajari.

\section{Bagaimana memilih model/metode pembelajaran ?}

Dalam memilih model/metode pembelajaran perlu disesuaikan program outcomesnya (kompetensi), misalnya kompetensi pengamatan, kompetensi penyusunan hipotesis, kompetensi pembuatan grafik, penguasaan rumus dan lain sebagainya, maka model atau metode tentu akan berbeda. Unsur-unsur lain selain 
kompetensi yang perlu diperhatikan dalam memilih model pembelajaran, yaitu sarana/alat, materi ajar (bahan ajar), siswa. Sarana/alat bila dihubungkan dengan bahan ajar, maka akan menjadikan bahan ajar menjadi efektif, bahan ajar apabila dihubungkan dengan siswa, maka perlu meninjau tingkat kesukaran/tingkat kemampuan, dan sarana/alat bila dihubungkan dengan siswa, maka hendaknya akan mewujudkan efesiensi pembelajaran.

Peran guru dalam paradigma baru pembelajaran adalah sebagai fasilitator: memfasilitasi buku, modul ajar, hand-out, journal, hasil penelitian (sebagai sumber belajar), dan waktu. Guru sebagai motivator dapat dilakukan dengan memberi perhatian pada siswa, memberi materi yang relevan dengan tingkat kemampuan siswa, dan dengan situasi yang kontekstual, memberi semangat dan kepercayaan pada siswa bahwa mereka dapat mencapai kompetensi yang diharapkan, memberi kepuasan pada siswa terhadap pembelajaran yang dijalankan. Guru juga memberi tutorial, yaitu menunjukkan jalan/cara/metode yang dapat membantu siswa menelusuri dan menemukan penyelesaian masalah yang berkaitan dengan materi pembelajaran. Guru juga sangat perlu memberi umpan balik, yaitu memonitor dan mengoreksi jalan pikiran/hasil kinerja siswa agar mencapai sasaran yang optimum sesuai kemampuannya.

\section{E. Penutup}

Penerapan model pembelajaran secara benar mengikuti sintaknya serta sesuai karakter materi, serta karakter siswa, maka penerapan model pembelajaran yang didahului dengan suatu pengembangan diharapkan mampu meningkatkan kualitas pembelajaran sehingga berdampak dari output hasil belajar siswa yang lebih baik. Beberapa penelitian menunjukan bahwa pembelajaran berbasis masalah ketika di terapkan dapat meningkatkan hasil belajar siswa (Ismail 2017). Begitu juga dengan model pembelajaran Children Learning In science beberapa penelitian menunjukan bahwa penerapan model pembelajaran CLIS mampu meningkatkan kualitas pembelajaran di kelas dan mampu meningkatkan penguasaan konsep siswa,keterampilan berfikir kritis siswa serta prestasi belajar siswa (Ismail 2015)

\section{Daftar Pustaka}

Arends, Richard I. 1997. Classroom Instructional and Management. The McGraw- Hill Cpmpanies, Inc.

Depdiknas. (2003). Kamus Besar Bahasa Indonesia, Edisi Ketiga. Jakarta: Balai Pustaka

Driver. R. (1988). "changing conceptions". Journal research in education 161-196.

Duch, J.Barbara. 1995. Problem Based Learning in Physics: The Power of Student Teaching Student. [Online]. Tersedia: http://www.udel.edu/pbl/cte/jan95phys.html .

Duch, J. Barbara. 1995. What is Problem-Based Learning?. [On Line]. Tersedia : http://www.udel.edu/pbl/cte/jan95-what.html

Duch,J.Barbara.2001.The Power Of Problem Based Learning.Virginia:Sterling. 
Glazer, Evan. 2001. Problem Based Instruction. In M. Orey (Ed.), Emerging perspectives on learning, teaching, and technology [Online]. Tersedia: http://www.coe. uga.edu/epltt/ProblemBasedInstruct.htm.

Ismail, A. (2017). Penerapan Model Pembelajaran Berbasis Masalah Untuk Meningkatkan Hasil Belajar Fisika Siswa Pada Pokok Bahasan Listrik. Gema Wiralodra, 8(2).

Ismail, A. (2017). Penerapan Model Pembelajaran Children Learning in Science (CLIS) Berbantuan Multimedia untuk Meningkatkan Keterampilan Proses Sains Siswa SMA pada Pokok Bahasan Fluida. JIPFRI (Jurnal Inovasi Pendidikan Fisika Dan Riset IImiah), 1(2), 83-87.

Ismail, A. (2015). Penerapan Model Pembelajaran Children Learning In Science (CLIS) Berbantuan Multimedia Untuk Meningkatkan Penguasaan Konsep Fisika Siswa SMA. JURNAL PETIK, 1(1), 19-25.

Ismail, A. (2012). Implementasi Model Pembelajaran Children Learning In Science (CLIS) untuk Meningkatkan Prestasi Belajar Siswa. Bandung: Diakses melalui repository. upi. edu pada tanggal, 8.

Ismail. (2003). Media Pembelajaran (Model-model Pembelajaran), Modul Diklat Terintegrasi Berbasis Kompetensi Guru Mata Pelajaran Matematika. Jakarta: Direktorat PLP

Joyce., B., Weil, M., \& Shower, B. (1992). Models of teaching (4 th ed). Englewood Cliff, N.J: Prentice-Hall.

Karim, S., et al (2007). Penerapan Pendekatan Pembelajaran Berbasis Masalah untuk Meningkatkan Penguasaan konsep Fisika serta Mengembangkan Keterampilan Berpikir Tingkat Tinggi dan Kecakapan Ilmiah. Proposal Hibah Kompetitif UPI 2007. Bandung: Tidak diterbitkan

Major, Claire, $\mathrm{H}$ dan Palmer, Betsy. 2001. Assessing the Effectiveness of Problem-Based Learning in Higher Education: Lessons from the Literature. [On line]. Tersedia : www.rapidintellect.com/AE Qweb/mop4spr01.htm

Nurhasanah. (2007). Pembelajaran Berbasis Masalah Untuk Meningkatkan Penguasaan Konsep, Berpikir Kritis dan Sikap IImiah. Tesis UPI Bandung: tidak diterbitkan.

Ruseffendi. 1980. Pengajaran Matematika Modern Untuk Orang Tua Murid Guru dan SPG seri 5. Bandung: Tarsito.

Savery, John.R, Duffy, Thomas.M. (1995). Problem Based Learning : An Intructional Model and Its Constructivist Framework. Bloomingtoon : Indiana University. [online].Tersedia: http://www.pbli.org/pbl/pbl.htm[

Soedjadi, 1999. Kiat Pendidikan Matematika Di Indonesia.(Departemen pendidikan dan Kebudayaan Direktorat Jendral Pendidikan Tinggi)

Wina Sanjaya. (2007). Strategi Pembelajaran Berorientasi Standar Proses Pendidikan. Jakarta: Kencana Prenada Media Group 